\title{
Water and the Struggle for Public Space: Social Negotiations in the Usage of Colonial Rio de Janeiro's Waterworks ${ }^{1}$
}

Jorun Poettering

DOI - 10.25160/v5i2.d7

Water affects social organization. The need for water invokes people to come into contact, to cooperate, to compete, or even to fight. While, on the one hand, water management is determined by a society's hierarchies, tensions, values, and traditions, on the other, it also contributes to shape them. Aqueducts and fountains materially retain key aspects of social organization. In this article, I will study the waterworks of colonial Rio de Janeiro, interpreting their construction and the subsequent ways they were used in the context of a continuous negotiation between two major groups of inhabitants, whom I call "white elites" and "Afro-Brazilians." I argue that both groups imbued the spaces created by and around the water supply infrastructure with a specific identity, giving the city its unique appearance. The white power elites, supported by technical experts, were active in the name of the Portuguese king and municipal authorities. They adopted concepts of conquest and civilization stemming from Roman traditions when designing the aqueducts and fountains and overseeing their usage. The slaves, who in their function as water carriers and laundresses, were the direct users of the infrastructure, filled the facilities with the pulse of life, giving them their special atmosphere. The two groups had different ideas about the value and functionality of the waterworks. On the basis of what we know from the sources, they rarely engaged in direct dialogue about the use and organization of the infrastructure and its surrounding spaces; rather, they negotiated them through their respective behaviors. After a short presentation of the waterworks, I will examine the meaning that the aqueduct and fountains had for the elites, then explore their appropriation by the slaves, and finally discuss the reactions of the elites.

\footnotetext{
${ }^{1}$ The research for this article was enabled by generous grants from the Alexander von Humboldt Foundation and the European Union's Horizon 2020 research and innovation program under the Marie Skłodowska-Curie grant agreement No. 659520. Parts of the argument were also used in a chapter entitled "Between Roman Models and African Realities. Waterworks and Negotiation of Spaces in Colonial Rio de Janeiro" (in New Worlds: Frontiers, Inclusion, Utopias, ed. Claudia Mattos Avolese and Roberto Conduru (São Paulo: CBHA/CIHA/Vasto, 2017), 133-145). I thank Martin Biersack and Kilian Harrer for their helpful comments.
} 


\section{The material configuration of the waterworks}

The city of Rio de Janeiro was founded in 1565 by the Portuguese crown. After provisionally erecting the city at the entry of Bay of Guanabara, the inhabitants relocated it in 1567 to the top of a nearby hill, which later became known as Morro do Castelo. After only a few decades, however, the population had grown so much that the settlement was relocated to the plain below. Since most of the city's lowlands was swampy and covered with lagoons and mangrove, the groundwater was largely brackish and almost no drinking water was available in the town. But there were several rivers coming from the nearby mountains, the most important of which sprang from the ridge of the Corcovado. Called the Carioca River, it emptied into the sea about 2.5 kilometers south of the old city, in today's neighborhood of Catete. Since the days of the early settlement, Amerindian and later African and Afro-Brazilian slaves were sent to the Carioca to fetch water and bring it into town in jugs or barrels.

Already in the first decade of the seventeenth century, the city fathers decided to construct an aqueduct that would carry water closer to the city. After several unsuccessful attempts, construction work on the aqueduct finally began in the late 1650s. Yet, delays occurred time and again. Originally the aqueduct was to terminate at Campo da Ajuda outside the city, in today's Cinelândia district; it was largely completed to that point, where the water probably flowed into a provisional fountain. But the course of the aqueduct was afterwards altered substantially, and the endpoint was located further on towards the city so that the water flowed into a fountain at the Largo de Santo Antônio, today's Largo da Carioca. Yet even this aqueduct, which was completed in 1723, did not remain in operation for long. Around 1740, work began for replacing the structure with a new one that had a straighter course, although with the same starting point and endpoint. That structure was completed by 1750 and has characterized Rio's cityscape down to the present. Aeneas Anderson, a member of a British diplomatic mission stopping over in the city in 1792, described this aqueduct as follows:

On the north-west side of the town there is a stupendous aqueduct, which is an object of uncommon curiosity. It is in the form of a bridge, contains eighty arches, and in some parts is, at least, one hundred and fifty feet in height; and is seen, in some points of view, with peculiar effect, rising 
gradually above the loftiest buildings of the city. This immense chain of arches stretches across a valley, and unites the hills that form it. ${ }^{2}$

The aqueduct fed a fountain with sixteen bronze spouts, which remained the most important water site for water carriers and laundresses until the end of colonial times. Around 1750, a second fountain was built at Carmo Square, the main square of the city, near the harbor, but in 1789, it was dismantled and replaced by a new one directly situated at the quayside. From the 1770s onwards, several more fountains were constructed at different places in the town, most of them being fed by subterranean conduits derived from the Carioca aqueduct.

\section{Traditions and values of the Portuguese colonial power}

As the Spanish nobleman Juan Francisco de Aguirre remarked after visiting Rio de Janeiro in 1782, the patricians of Rio were extraordinarily proud of their grand Carioca aqueduct - so proud that those born in Rio were generally called "Cariocas", a designation still common today for the natives of the city. ${ }^{3}$ Its construction can be placed within a long tradition of Portuguese aqueduct building. It goes back to the Romans who erected a large number of impressive aqueducts in their Lusitanian province, like those in Évora, Elvas, Setúbal, and Coimbra, which still can be visited today. They were thoroughly renewed and expanded in the 16th century. ${ }^{4}$ In particular, the humanistically oriented King João III (1502-1557) had a great interest in maintaining and restoring Roman culture and architecture, not least because he considered the Portuguese overseas empire to be a successor to the former Roman empire. João III promoted trips by Portuguese artists to Italy so they could study Roman heritage as well as the restoration concepts of the Renaissance and apply them to Portugal. One of the artists patronized by the Crown was the architect and painter Francisco de Holanda (1517-1584), who visited Rome as a young man in 1538-39. Many years later, he wrote a report in which he described his travel experiences in Rome and proposed a program for the urbanistic reconfiguration of Lisbon,

\footnotetext{
2 Aeneas Anderson, A narrative of the British embassy to China in the years 1792, 1793, and 1794 (London: J. Debrett, 1795), 22.

3 "Tiene tal estimacion esta obra entre estos patricios que la manifestan como cosa que merece la estimacion [...]. De esta admiracion por el acueducto ha resultado que los criollos de este Rio sean conocidos por el sobrenombre de Cariocas [...]"; Juan Francisco de Aguirre, "Diario de Aguirre," Anales de la Biblioteca 4 (1905): 72.

${ }^{4}$ Walter Rossa, "Modern Age Aqueducts in Portugal," in Aqueducts, ed. Vittorio Gregotti (Bologna: CIPIA, 1994), 6162.
} 
including the construction of an aqueduct based on the Roman paradigm. ${ }^{5}$ His argument was that, if Lisbon aspired to become the greatest and noblest city on earth, it would also have to provide sufficient water to supply the needs of people from the entire planet. As had been the case in the Renovatio Romae, the program carried out by the Renaissance Popes to resurrect Rome as the center of Christendom, he closely associated the architectonic renewal of the city with the religious purification of the souls of its residents. ${ }^{6}$

In his narrative of the Roman conquest of Lisbon in the second century $\mathrm{BC}$, Holanda followed a paradigm typical of Portuguese humanism: ${ }^{7}$ on the heels of the Roman victory over the local pagans came urbanization, embellishment, and aristocratization of the city that had been conquered. In addition to the construction of temples and fortifications, walls and palaces, a system for water provision with large arches and an extensive network of pipes had been of particular importance according to Roman understanding. Holanda believed that the Portuguese king and the burghers of Lisbon ought to embrace that paradigm, too. Comparable conceptions existed regarding the establishment of cities in the colonial world. In his Delle cause della grandezza $e$ magnificenza delle città (1588), the Italian philosopher Giovanni Botero cites the case of Brazil in order to explain how human beings should be both civilized and converted to Christianity by means of urban life:

A similar thing is being done constantly in Brazil, whose people live scattered here and there in caves or in huts built from the branches and fronds of palm trees, and not in houses. Because they live dispersed like this, the people retain their savage mentality and their rude customs, which makes it hard to preach the Gospel, convert unbelievers, instruct those who are gradually converted, and bring them under civil government. So the Portuguese and the Jesuit Fathers use every means to

\footnotetext{
5 Francisco de Olanda, Da fabrica que falece a cidade de Lisboa, ed. Vergilio Correia and Alberto Cortês (Madrid: Centro de Estudios Históricos, 1929).

${ }^{6}$ Katherine Wentworth Rinne, The Waters of Rome. Aqueducts, Fountains, and the Birth of the Baroque City (New Haven: Yale University Press, 2010), 45. For a similar interpretation cf. Ronald K. Delph, "Renovatio, Reformatio, and Humanist Ambition in Rome," in Heresy, culture, and religion in early modern Italy. Contexts and contestations, ed. Ronald K. Delph, Michelle M. Fontaine and John Jeffries Martin (Kirksville, MO: Truman State University Press, 2006), 85; Charles L. Stinger, "Roman Humanist Images of Rome," in Roma capitale, 1447-1527, ed. Sergio Gensini (Pisa: Pacini, 1994), 32-33.

${ }^{7}$ Most prominently André de Resende, see Bento Jozé de Souza Farinha, ed., Colleçam das antigvidades de Evora escriptos por Andre de Rezende, Diogo Mendes de Vasconcellos, Gaspar Estaço, Fr. Bernardo de Brito, e Manoel Severim de Faria (Lisbon: Officina de Filippe da Silva e Azevedo, 1785); André de Resende, As Antiguidades da Lusitânia, ed. Raul Miguel Rosado Fernandes (Coimbra: Impr. da Univ. de Coimbra, 2009).
} 
gather them together in the most suitable places, where, following a civilized manner of life, they may be more easily instructed in the Christian faith by the Fathers, and governed by the king's officials. ${ }^{8}$

To be clear, the Brazilian settlements to which Botero is referring were the aldeamentos founded by the Jesuits, where the indigenous population was to be missionized - not cities like Rio de Janeiro, which were built mostly for white immigrants. Nonetheless, in connection with further thoughts that Botero developed in his treatise, the passage shows the importance of the city as a place of civilized life according to European perception. Urbanity, with its specific architecture and political organization, was a central part of the identity of European settlers in America. As solid material testimony accessible for everybody to see, the city also represented the nonmaterial culture spread by the Europeans and vaunted as their own. Just as Roman conquerors had established cities in Portugal reflecting the model of their imperial capital, including the establishment of aqueducts, so did the Portuguese who built cities with similar features in the areas they had conquered and settled.

The aqueduct in Rio de Janeiro, however, was not built when the Portuguese founded the city, but was completed only more than 150 years later. As a matter of fact, urbanization in Portuguese America as a whole came very late. The Portuguese engagement in colonialism remained focused for quite some time on the Asian territories of their global colonial empire. Only toward the end of the seventeenth century did the crown seek to gain stronger control over Portuguese America. It started to intensify urbanization, dispatched experts, and opened academies in several Brazilian towns for training engineers. ${ }^{9}$ In addition, gold was discovered in the interior, not only making the country suddenly quite profitable, but also promoting Rio de Janeiro to a central export hub, increasing its importance substantially. The crown made massive investments in the cityscape. In 1698, it purchased one of the most elegant houses in the city for the governor's official seat. A bit thereafter, it had a house built for storing royal instruments and papers, the Casa dos Contos. Then it had a mint constructed in the immediate vicinity of the town hall, and, in the mid-1720s, it initiated the construction of a new governor's

\footnotetext{
8 Giovanni Botero, On the Causes of the Greatness and Magnificence of the Cities, ed. Geoffrey Symcox (Toronto: University of Toronto Press, [2012]), 10.

9 Beatriz Piccolotto Siqueira Bueno, Desenho e desígnio. O Brasil dos engenheiros militares (1500-1822) (São Paulo: EDUSP, 2011).
} 
palace on the Carmo Square, which by then had become the central urban square. ${ }^{10}$ The completion of the aqueduct should be viewed in the context of these urban reconfigurations reflecting an enhanced political interest.

Through constantly visible inscriptions on the aqueduct and fountains, a lasting connection was communicated to the inhabitants of Rio de Janeiro between the material reality of the city and the commitment of the colonial representatives. On the Carioca fountain, a stone tablet stated that it was built at the time of Governor Aires de Saldanha. At the upper end of the waterworks, an inscription read that this segment of the aqueduct had been constructed under King João V and Governor Gomes Freire de Andrade in 1744. At the aqueduct's lower end, under one of the arches, it is still possible to read that the structure was completed as commissioned by this same king and governor in 1750 . The inscriptions on two fountains built in 1772, in Matacavalos and Glória, connect them to the tenure of the Marquis of Lavradio; the Marrecas fountain, finished in 1785, and a second Carmo fountain, built in 1789, recall the Viceroy Luís de Vasconcelos. The Capim fountain, constructed shortly before the end of the eighteenth century, and the Moura fountain mention his successor, the Count of Resende. Almost all these inscriptions were in Latin. ${ }^{11}$ The one on the second fountain in Carmo Square was especially detailed, alluding to a myth from classical antiquity: it juxtaposed Phoebus, bringer of fire that consumes whole nations, and the Viceroy Vasconcelos, bringer of water, who expels thirst from the city. ${ }^{12}$ Even more than the other inscriptions, this one evokes the Roman prototype of the structures and the associated conceptions of colonization and civilization.

\section{Bringing to life the waterworks}

The inscriptions on the fountains were a cause of pride and satisfaction for educated contemporaries, such as the churchman and chronicler José de Sousa Azevedo Pizarro e Araújo (1753-1830), who carefully noted them in his comprehensive history of the city of Rio de Janeiro and its surroundings. Yet those who made use of the fountains and regularly saw the inscriptions were almost exclusively slaves and freed slaves, who found

\footnotetext{
${ }^{10}$ Mauricio de Almeida Abreu, Geografia Histórica do Rio de Janeiro (1502-1700), vol. 2 (Rio de Janeiro: Andrea Jakobsson, 2010), 310. The Carmo Square was officially declared a square only in the 1680s; Abreu, Geografia Histórica, vol. 2, 293, 300.

11 José de Souza Azevedo Pizarro e Araújo, Memorias historicas do Rio de Janeiro e das provincias annexas à jurisdição do vice-rei do Estado do Brasil, vol. 7 (Rio de Janeiro: Silva Porto, 1822), 54-65.

12 "Ignifero curru populos dum Phoebus adurit, / Vasconcellus aquis ejcit urbe sitim / Phoebe retro propera: et Coeli statione relicta, / Praeclaro potius nitere adesse Viro.” Araújo, Memorias historicas, 58.
} 
little to identify with in these Latin flourishes. For them, the structures represented a place of labor as well as an area for meeting and recreation. In numerous European travel accounts written at the end of the eighteenth and beginning of the nineteenth centuries, the spaces around the fountains were described as extremely loud and chaotic due to the large numbers of Africans and Afro-Brazilians who congregated there. As a fountain where people also did their laundry, the loud smack as clothing was beaten to remove the dirt and water further increased the noise level in addition to everybody's shouts and conversations. ${ }^{13}$

Often the water carriers had to endure a long wait until they could fill their vessels, but sometimes they would also use the opportunity to deliberately take a break from the activities. The Englishman James Hardy Vaux, who visited Rio in 1807, described the following scene:

As the trade of water-carrying furnishes employment for many hundreds of negro women, and their continual resort to the fountains would occasion much confusion and quarrelling, a soldier is placed in attendance to preserve order, and the women seat themselves in a row on a long bench fixed on purpose, where they are obliged to wait for their turn to fill. It is a curious and interesting sight to observe these harmless and industrious creatures conversing with each other, and smoking their pipes, while they patiently await the sentinel's intimation to approach. The incessant prattle of their tongues may be heard by a passenger long before he reaches the spot, and adds to the novelty of the scene. ${ }^{14}$

The fountains were places where the slaves and freedmen could socialize as they conversed, smoked, ate, drank, played and occasionally even took a bath. They turned into spaces of community life where Afro-Brazilians could pursue those social needs that whites satisfied in the private spheres of their homes and gardens. It was a freely accessible, openly observable, often chaotic, and yet intimate space of the black population where their own rules and hierarchies held sway.

The sentinel described by James Hardy Vaux was a figure who constantly appeared in descriptions of the fountains. Already from the time shortly after the completion of the

\footnotetext{
13 John Luccock, Notes on Rio de Janeiro and the southern parts of Brazil; taken during a residence of ten years in that country, from 1808 to 1818 (London: Samuel Leigh, 1820), 77.

14 James Hardy Vaux, Memoirs of James Hardy Vaux, vol. 1 (London: W. Clowes, 1819), 219.
} 
Carioca fountain, observers reported violent quarrels erupting from the gatherings of the blacks. ${ }^{15}$ Members of the municipal council complained not only that slaves were fighting, but also that they were destroying the aqueduct. Governor Luís Vaía Monteiro, in power at that time (1725-1732), rejected the charge that the slaves were purposefully damaging the structure. Yet he confirmed that they gathered near the fountain in order to gamble, a diversion that led to many an argument and dispute. For that reason, he ordered the soldiers to arrest slaves playing at those places and to take away their money. ${ }^{16}$

This procedure throws light on a central problem of colonial society: idle slaves seemed objectionable to the white elites, if not downright dangerous. As the Jesuit Jorge Benci wrote in a tractate published in 1700, a double threat emanated from them. ${ }^{17}$ On the one hand, idleness led to vices and a life of sin. Benci claimed that, while this was also true of the whites, the Africans and Afro-Brazilians were much more prone to all manner of outrages. Yet idleness was not only an insult to the Lord, it also represented a concrete risk for the whites, since it provoked slaves into being rebellious and recalcitrant; they even might try to shake off the yoke of slavery. For that reason, Benci warned the slaveholders to make sure their slaves were constantly kept busy at work. In this way, they would remain peaceable and tame, ensuring that their masters could lead a relaxed and quiet life. The growing number of freed slaves likewise posed a problem in the perspective of the people of European origin: socially marginalized and with few legal possibilities for work, they were considered lazy, vicious, and depraved. ${ }^{18}$ Like the slaves, the freedmen would also congregate at the fountain. For the white elites, this constituted a threat to social order.

In contrast to what Governor Vaía Monteiro thought, slaves who gathered near the fountain were not only busy with gambling. Both the destruction (as we will see in the next section) and the fights seemed to have been part of everyday reality, and by no means

\footnotetext{
15 Arquivo Nacional, ed., Publicações Históricas 15 (Rio de Janeiro: Ministério da Justiça, 1915), 254; Arquivo Nacional (AN), Secretaria de Estado do Brasil, cód. 952, vol. 24, f. 305.

16 Arquivo Nacional, Publicações Históricas 15, 254-255.

17 Jorge Benci, Economia cristã dos senhores no governo dos escravos (livro brasileiro de 1700), ed. Pedro de Alcântara Figueira and Claudinei M. M. Mendes (São Paulo: Grijalbo, 1977), 175-178.

18 "The Brazilians are much in the habit of freeing their slaves, but to judge by the usual effects of enfranchisement, the negro had better remain in the trammels of slavery. The free blacks are usually idle, vicious, and disorderly. From being turned on the world when unfit for it, and unaccustomed to spend a moment in thought, they are improvident, and in most instances become a disgrace to themselves, and a bad example to their former companions. [...] If the effects of enfranchising slaves are upon the whole so little beneficial to themselves and dangerous to the whites, - and this is a truth which all who have spent some time in a slaveholding country will readily concede,- - it becomes a question what is to be the remedy." Alexander Caldcleugh, Travels in South America during the years 1819-20-21. Containing an account of the present state of Brazil, Buenos Ayres, and Chile, vol. 1 (London: John Murray, 1825), 86-87.
} 
did the disputes always end in a harmless way. The sources repeatedly make mention of persons injured or killed at the fountains. ${ }^{19}$ The reasons for the conflicts certainly lay much deeper than just in gambling or some petty argument over water. Although the white slave owners complained about the quarrels, they actually actively aggravated the tensions. They strategically brought slaves from different African nations that were at enmity with each other as a strategy for preventing solidarity from emerging and inhibiting the outbreak of slave revolts. ${ }^{20}$

\section{A contested space}

The noisy, chaotic and at times violent scenes at the fountains could hardly be harmonized with the previously described values of the civilized urbane world manifested in the elegance of the architecture, representing an allegedly republican form of society and the sublimity of Christian forms of living. The Afro-Brazilians had appropriated the spaces created by the water supply infrastructure: their life realities overlay and submerged the urban identity postulated by the white elites. They imbued these public spaces with a peculiar physiognomy in keeping with their situation and ways of being. But the municipal administration reacted and sought nonetheless to enforce its conceptions. This was done by a variety of means in addition to the sentinels stationed at the fountains to discipline the Africans and Afro-Brazilians.

The very erection of the aqueduct can be interpreted as a means to control the slaves' activities. In the documentation, the construction was legitimated by reference to the distance between the city and the Carioca River. ${ }^{21}$ However, by the time of the first plans for the aqueduct, the city had a white population of only between 3,500 and 7,500 people, ${ }^{22}$ and the distance on foot of some two to three kilometers to the river was hardly a great effort for a society helped by slaves. But with the aid of the aqueduct, it would be easier to keep slaves under surveillance. If they fetched water at a fountain near the city instead of being sent outside of it, they remained under the eyes of residents and authorities - or at least had to fear being observed much more. It should be noted that the

\footnotetext{
19 AN, Secretaria de Estado do Brasil, cód. 952, vol. 24, f. 254; vol. 27, f. 302; cód. 61, vol 18, f. 437-440; Arquivo Histórico Ultramarino (AHU), ACL, CU, 017, cx. 34, doc. 3579.

${ }^{20}$ Robert Walsh, Notices of Brazil in 1828 and 1829 in two volumes. vol. 2 (Boston: Richardson, Lord \& Holbrook, 1831), 182.

${ }^{21}$ José Carlos de Macedo Soares, ed., Livro primeiro do governo do Brasil, 1607-1633 (Rio de Janeiro: Seção de Publicações do Serviço de Documentação, 1958), 282; AHU, ACL, CU, 017-01, cx. 27, doc. 6111.

${ }^{22}$ Abreu, Geografia Histórica, vol. 1, 20.
} 
slaves in the city had much greater freedom of movement than those in the plantations. The water carriers were either domestic slaves or so-called escravos de ganho (literally, "profit slaves"), who passed through town on their own, selling water and then passing on the money collected to their masters as profit. The dangers or anxieties associated with slaves who were roaming around freely in town show up in a couple of prohibitions issued since the seventeenth century, forbidding slaves who were not accompanied by their masters from carrying knives, bows and arrows, clubs, or other weapons. ${ }^{23}$ On the way to the river, the slaves could also find a chance to flee, disappear into the forests, and join one of the quilombos, the settlements of escaped slaves. Another fear haunting the municipal administration was that the slaves might enter one of the taverns along the route. These were supposedly not just hideouts for escaped slaves, but also places where slaves could sell goods they had stolen, besides purchasing alcohol and narcotics. In 1671, the municipal council thus prohibited the construction of taverns in the area between the churches Nossa Senhora da Ajuda, Nossa Senhora do Parto, and the lagoon of Santo Antônio, an area the slaves passed through on their way to the Carioca River and where the aqueduct originally was supposed to end.

What actually led to the change in direction of the first aqueduct and the reconstruction of the second one is not entirely clear. The correspondence between the governors and the Overseas Council mentions various errors in construction. Thus, the first aqueduct was built with the wrong gradient and the second had a zig-zag design that created too much resistance for the flow of water. ${ }^{24}$ But it is also conceivable that the reason for relocating the endpoint of the first aqueduct was to bring the fountain closer to the city to ensure easier supervision of the slaves attending the facility. It is also probable that the slaves were at least partly to blame for the oft-lamented ruinous condition of the second aqueduct. The damages attributed to the slaves were generally associated with their supposedly crude behaviors, but sometimes they were also alleged to have been caused intentionally. Thus, the slaves reportedly damaged the aqueduct in order to divert water. The authorities reacted to this "barbarian act," as the destruction was termed in one source, by closing the covers necessary for purposes of cleaning and repair even more tightly and by installing them so high above ground that the slaves would not be able to reach them. ${ }^{25}$ On other parts, a covering with a ridge was installed on top of the aqueduct

\footnotetext{
${ }^{23}$ Abreu, Geografia Histórica, vol. 2, 448-449.

24 AN, Secretaria do Estado do Brasil, cód. 952, vol. 11, f. 163; vol. 29, f. 168; AHU, ACL, CU, 017-01, cx. 43, doc. 10397.

2525 AN, Secretaria de Estado do Brasil, cód. 952, vol. 33, f. 335.
} 
to prevent people from walking on it and damaging it in the process. ${ }^{26}$ The selection of stone pipes instead of the cheaper clay pipes was justified by stating that these would last "forever" and did not require constant repair. ${ }^{27}$ Misuse at the fountains was to be combatted by installing the water tanks so far from the faucets that the slaves could not hit them. ${ }^{28}$ And most contemptuously, the Overseas Council rejected a proposal by the Brazilian engineer José Fernandes de Alpoim for the construction of the Carmo fountain, because its structure was deemed too delicate for the slaves. ${ }^{29}$ Measures for the repair or security of the installations were not exclusively due to destruction by Afro-Brazilians. Being the principal users, however, they were often the ones causing such damage, whether consciously or through negligence. The slaves did not necessarily appreciate the functionality of the aqueduct. Nor did the water system's role for the image of urban culture and refinement cherished by the white elites hold much value for the slaves. Thus, the interplay of construction and reconstruction measures and the decline in the condition of the aqueduct and fountains can be interpreted in the context of the existing tensions between the white builders and the black users.

The municipal deputies wanted not only to limit the material destruction of the facility; they also wished to curtail the level of chaos at the water sites. One remedy was the construction of additional fountains. Thus, the authorities declared that setting up the Carmo fountain "promoted public well being [...] by preventing crowds of Afro-Brazilians mingling, which has repeatedly led to quarrels, fights, and injuries." ${ }^{30}$ No mention was made of the fact that this fountain would also shorten the distance between the water facility and the households in an especially densely populated section of the town. The goal was to prevent excessively large crowds of slaves from gathering in a single placebe it just to ensure more quiet or because the city fathers actually assumed there was a danger for the residents emanating around the fountain. ${ }^{31}$

\footnotetext{
${ }^{26}$ AHU, ACL, CU, 017-01, cx. 43, doc. 10397.

${ }^{27}$ AHU, ACL, CU, 017-01, cx. 44, doc. 10400.

28 "O que o provedor reprezenta de serem os chafarizes maltratados dos negros tem remedio, fazendo se os tanques tão distantes das bicas que os escravos as não possão tocar.” AHU, ACL, CU, 017, cx. 34, doc. 3579.

29 “[...] é de obra muito mais miuda do que convém para o uso dos negros que brevemente a destruiram." A further reason mentioned was that it was not in as fine and refined taste as it might be if designed in Lisbon. Revista do Archivo do Distrito Federal, vol. 4 (1897), 464.

30 “[...] seguisse o comodo publico [...] fazendose menos ajuntamentos de negros que fazem repetidas pendencias inquietacões e ferimentos.” AN, Secretaria de Estado do Brasil, cód. 952, vol. 27, f. 302.

${ }^{31}$ The Overseas Council argued along similar lines when, a bit later, it pleaded for distributing water to all sections of the city - a plan that, in the form envisioned, was never implemented. Revista do Archivo do Distrito Federal, vol. 4 (1897), 465.
} 
Although the Carmo fountain was planned for practical use, its construction was also a reflection of the growing functional and social differentiation of the urban space. Unlike the Carioca fountain, which at this time it was erected was still located on the periphery of the city, ${ }^{32}$ the Carmo fountain was built in the very heart of the political and representative center of Rio de Janeiro. It was a waterspout fountain that was supposed to be the primary ornament to the newly designed Carmo Square opening onto the town's harbor. The fountain symbolized the prosperity, level of order, and political importance attained by the city. In of one of its letters requesting the king's permission to build the fountain, the municipal council had argued that Rio de Janeiro was "one of the most notable [cities] in the expansive territories under the rule of His Majesty." 33 Therefore the Carmo fountain was to be designed with especial expense to serve as the "jewel of the city," while the additional fountains planned at this time were to be simpler in design, since their function was exclusively for the provision of water and a place for washing laundry. ${ }^{34}$

The slaves, however, appear to have been unimpressed by this differentiation. As we know from various sources, including the reports of the expedition under James Cook, which landed in Rio de Janeiro in 1768, it was difficult for the sentinels to preserve order among the slaves waiting at the Carmo fountain, even though they reportedly pursued their task with exceptional severity. ${ }^{35}$ Therefore, if the foreigners wished to fill water

\footnotetext{
32 32AHU, ACL, CU, 017, cx. 34, doc. 3579. The Marquis de Lavradio also wrote that, before he had built the fountains, the slaves had to fetch water in the "[...] subúrbios da cidade em partes distantes [...]"; Luiz de Almeida Portugal / Marquês do Lavradio, Cartas do Rio de Janeiro: 1769-1776 (Rio de Janeiro: Arquivo Nacional, 1978), 126 (11.6.1773).
}

${ }^{33}$ AHU, ACL, CU, 017, cx. 34, doc. 3579. Shortly thereafter (1749), an official of the king (ouvidor) justified another municipal construction measure by saying that Rio de Janeiro soon would even be able to claim it was the first city in all of America: "E porque esta Cidade pellos tempos em diante pode vir a Ser a primeira de toda a America [...]" if the buildings were regularly aligned along the streets; Eduardo Tourinho, ed., Autos de Correições de Ouvidores do Rio de Janeiro, vol. 3 (1748-1820) (Rio de Janeiro: Prefeitura do Districto Federal, 1931), 7.

${ }^{34}$ Revista do Archivo do Distrito Federal, vol. 4 (1897), 465.

35 "At this fountain great numbers of people are continually waiting for their turn to draw water; and the soldiers, who are posted at the Governor's door, find it very difficult to maintain any regularity among them." John Hawkesworth, $A n$ account of the voyages undertaken by the order of His present Majesty for making discoveries in the Southern Hemisphere, vol. 2 (London: W. Strahan and T. Cadell, 1773), 27-28; “[...] and it [s] likewise here that the ships water: they land their Casks upon a smooth sandy beach about one hundred yards from the fountain, and upon application to the Viceroy you have a Centinal to look after them and to clear the way for to come at the fountain to fill your water." John Cawte Beaglehole, ed., The voyage of the Endeavour, 1768-1771. The journals of Captain James Cook on his voyages of discovery (Cambridge: Hakluyt Soc. at the Univ. Press, 1968), 29-34. There is a similar report by the physician John White regarding his visit in 1787: "This convenient and capital watering place is so near the palace that when disputes or contentions arise between the boats' crews of different ships, the slaves, etc. they are suppressed and adjusted by the soldiers on guard, who, in the Portugueze service, have great power and often treat the people with no little severity." John White, Journal of a Voyage to New South Wales (London: J. Debrett, 1790), 60. 
storage casks for their ships, they could request their own especially assigned sentinel from the Viceroy. He then cleared their path to the fountain so that they could fill their containers there.

The tendency to divide the city into different sociofunctional spaces was also manifested in other urbanistic measures of the same time, such as the creation of a separate area for the slaves newly arriving from Africa in the Valongo district, as well as the establishment of a public garden for the more refined part of the society of Rio de Janeiro. The Viceroy Marquis of Lavradio explained the motives behind the first measure in a report on his tenure in office as follows:

There was in this city the most terrible of customs, namely that all blacks who arrived in the port from the coast of Africa, as soon as they had left the ships, went on into town, proceeding onto the public and main streets, not only full of illnesses and anguish, but also naked; since that sort of persons, as long as they are lacking any further education, are just like all other coarse savages [...] it was the most horrific spectacle that one might behold. The honorable residents no longer dared to even approach their windows; those who were innocent learned there what they as yet did not know and were not supposed to know [...].

Lavradio set up an area outside the city walls which was "cut off from all communication," the Valongo, in order to clear the central streets of the scenes he and his equals perceived to be an intolerable sight, but also in a bid to prevent the spread of epidemics purportedly transmitted by newly arrived slaves. ${ }^{36}$ His successor, Luís de Vasconcelos, opened a public park likewise located outside the city, although bordering the town on the south rather than the north. This was a, fenced-in garden area, covered with trees and endowed with a fountain. It offered space for leisurely strolls, musical events, and small festivals. From this area, one could admire the unique landscape of the

\footnotetext{
36 “Havia mais n'esta cidade o terrivel costume de que todos os negros que chegavam da costa d'Africa a este porto, logo que desembarcavam, entravam para a cidade, vinham para as ruas publicas e principaes d'ella, não só cheios de infinitas molestias, mas nús; como aquella qualidade de gente, em quanto não tem mais ensino, são o mesmo que qualquer outro bruto selvagem, [...] sendo o espectaculo mais horroroso que se podia apresentar aos olhos. As pessoas honestas não se atreviam a chegar às janellas; as que eram innocentes alli aprendiam o que ignoravam, e não deviam saber [...]”; “[...] é no suburbio da cidade, separado de toda a comunicação [...]”; Luiz de Almeida Portugal / Marquês do Lavradio, "Relatório do Marquez de Lavradio, vice-rei do Rio de Janeiro, entregando o governo a Luiz de Vasconcelos e Souza, que o sucedeu no Vice-Reinado," Revista do Instituto Histórico e Geográfico Brasileiro, vol. 4, n. 16 (1842), 450-451. See also Silvia Hunold Lara, Fragmentos setecentistas. Escravidão, cultura e poder na América portuguesa (São Paulo: Companhia das Letras, 2007), 64-65.
} 
bay while putting one's own prosperity on public display. ${ }^{37}$ Although nominally public, it was an ennobled space that was supposedly "liberated" from the gross chaos of the street and the disturbing sight of slaves hard at work or scantily clothed.

However, having a fountain in the public garden meant that the intended segregation was not achieved in this case either. As we know from sketches by the Austrian landscape painter Thomas Ender from 1817-1818, the slaves were fetching water from this fountain, too. ${ }^{38}$ By contrast, the white elites appear to have retreated from the place, and reports from this period repeatedly lament about how much the facility was declining. ${ }^{39}$

As the slaves were of such great importance for the daily provisioning of water to the residents, it was impossible to banish them from the public image of the city. The figure of the sentinel at the fountain, charged with ensuring law and order, was ultimately nothing but an expression of the abiding sense of helplessness on the part of the authorities faced with the realities created by the Afro-Brazilians along the water supply infrastructure-contrary to the visions of a public space as conceived by the white elites.

It was not until the early 1880s, shortly before the abolition of slavery, that a comprehensive water supply network with individual household provisioning was installed. Water carriers were no longer needed, and laundresses were relegated to the domestic sphere. It was the march of technology that finally defeated the black population in their appropriation of Rio's public spaces around water sites, suspending their essential role in the water distribution that had contributed so much to the shaping of the city.

\section{Conclusion}

The urban space of colonial Rio de Janeiro was structured by a water supply system drawn from European models, including aqueducts, fountains, and a network of underground pipes. This infrastructure, however, worked hand in hand with innumerable slaves responsible for the distribution of water from the fountains to individual households. There was a continuous negotiation between white elites and Afro-Brazilian slaves regarding the localization, construction, usage, and valorization of the water works and the spaces around them. While the elites possessed the power, means, and traditions

\footnotetext{
${ }^{37}$ Lara, Fragmentos setecentistas, 65-66.

${ }^{38}$ Robert Wagner and Julio Bandeira, ed., Viagem ao Brasil nas aquarelas de Thomas Ender, 1817-1818, vol. 2 (Petrópolis: Kapa, 2000), 453, 568, 577.
} 
to design the infrastructure in the first instance, the slaves gave life to it, defined their eventual application and appearance, and more than once also caused the white elites to modify the works. Thus, the slaves were able to actively participate in the configuration of the physical and cultural identity of colonial Rio de Janeiro.

\section{Primary Sources \\ Unpublished:}

Arquivo Histórico Ultramarino (Portugal).

Arquivo Nacional do Rio de Janeiro (Brazil).

\section{Published:}

Aguirre, Juan Francisco de, “Diario de Aguirre," Anales de la Biblioteca 4 (1905).

Anderson, Aeneas, A narrative of the British embassy to China in the years 1792, 1793, and 1794 (London: J. Debrett, 1795).

Araújo, José de Souza Azevedo Pizarro e, Memorias historicas do Rio de Janeiro e das provincias annexas à jurisdição do vice-rei do Estado do Brasil, vol. 7 (Rio de Janeiro: Silva Porto, 1822).

Achivo do Distrito Federal, ed., Revista do Archivo do Distrito Federal, vol. 4 (1897).

Arquivo Nacional, ed., Publicações Históricas 15 (Rio de Janeiro: Ministério da Justiça, 1915).

Beaglehole, John Cawte, ed., The voyage of the Endeavour, 1768-1771. The journals of Captain James Cook on his voyages of discovery (Cambridge: Hakluyt Soc. at the Univ. Press, 1968).

Benci, Jorge, Economia cristã dos senhores no governo dos escravos (livro brasileiro de 1700), ed. Pedro de Alcântara Figueira and Claudinei M. M. Mendes (São Paulo: Grijalbo, 1977).

Botero, Giovanni, On the Causes of the Greatness and Magnificence of the Cities, ed. Geoffrey Symcox (Toronto: University of Toronto Press, [2012]).

\footnotetext{
${ }^{39}$ For the position and spatial context of the other fountains cf. Alida C. Metcalf, "Water and Social Space: Using georeferenced maps and geocoded images to enrich the history of Rio de Janeiro's fountains," e-Perimetron, vol. 9, n. 3 (2014), 129-145.
} 
Caldcleugh, Alexander, Travels in South America during the years 1819-20-21. Containing an account of the present state of Brazil, Buenos Ayres, and Chile, vol. 1 (London: John Murray, 1825).

Farinha, Bento Jozé de Souza, ed., Colleçam das antigvidades de Evora escriptos por Andre de Rezende, Diogo Mendes de Vasconcellos, Gaspar Estaço, Fr. Bernardo de Brito, e Manoel Severim de Faria (Lisbon: Officina de Filippe da Silva e Azevedo, 1785).

Hawkesworth, John, An account of the voyages undertaken by the order of His present Majesty for making discoveries in the Southern Hemisphere, vol. 2 (London: W. Strahan and T. Cadell, 1773).

Luccock, John, Notes on Rio de Janeiro and the southern parts of Brazil; taken during a residence of ten years in that country, from 1808 to 1818 (London: Samuel Leigh, 1820).

Olanda, Francisco de, Da fabrica que falece a cidade de Lisboa, ed. Vergilio Correia and Alberto Cortês (Madrid: Centro de Estudios Históricos, 1929).

Portugal, Luiz de Almeida / Marquês do Lavradio, "Relatório do Marquez de Lavradio, vice-rei do Rio de Janeiro, entregando o governo a Luiz de Vasconcelos e Souza, que o sucedeu no Vice-Reinado," Revista do Instituto Histórico e Geográfico Brasileiro, vol. 4, n. 16 (1842).

Portugal, Luiz de Almeida / Marquês do Lavradio, Cartas do Rio de Janeiro: 1769-1776 (Rio de Janeiro: Arquivo Nacional, 1978).

Resende, André de, As Antiguidades da Lusitânia, ed. Raul Miguel Rosado Fernandes (Coimbra: Impr. da Univ. de Coimbra, 2009).

Soares, José Carlos de Macedo, ed., Livro primeiro do governo do Brasil, 1607-1633 (Rio de Janeiro: Seção de Publicações do Serviço de Documentação, 1958).

Tourinho, Eduardo, ed., Autos de Correições de Ouvidores do Rio de Janeiro, vol. 3 (1748-1820) (Rio de Janeiro: Prefeitura do Districto Federal, 1931).

Vaux, James Hardy, Memoirs of James Hardy Vaux, vol. 1 (London: W. Clowes, 1819).

Wagner, Robert and Julio Bandeira, ed., Viagem ao Brasil nas aquarelas de Thomas Ender, 1817-1818, vol. 2 (Petrópolis: Kapa, 2000). 
Walsh, Robert, Notices of Brazil in 1828 and 1829 in two volumes, vol. 2 (Boston: Richardson, Lord \& Holbrook, 1831).

White, John, Journal of a Voyage to New South Wales (London: J. Debrett, 1790).

\section{Secondary Sources}

Abreu, Mauricio de Almeida, Geografia Histórica do Rio de Janeiro (1502-1700), vol. 2 (Rio de Janeiro: Andrea Jakobsson, 2010).

Bueno, Beatriz Piccolotto Siqueira, Desenho e desígnio. O Brasil dos engenheiros militares (1500-1822) (São Paulo: EDUSP, 2011).

Delph, Ronald K., "Renovatio, Reformatio, and Humanist Ambition in Rome," in Heresy, culture, and religion in early modern Italy. Contexts and contestations, ed. Ronald K. Delph, Michelle M. Fontaine and John Jeffries Martin (Kirksville, MO: Truman State University Press, 2006).

Lara, Silvia Hunold, Fragmentos setecentistas. Escravidão, cultura e poder na América portuguesa (São Paulo: Companhia das Letras, 2007).

Alida C. Metcalf, "Water and Social Space: Using georeferenced maps and geocoded images to enrich the history of Rio de Janeiro's fountains," e-Perimetron, vol. 9, n. 3 (2014), 129-145.

Rinne, Katherine Wentworth, The Waters of Rome. Aqueducts, Fountains, and the Birth of the Baroque City (New Haven: Yale University Press, 2010).

Rossa, Walter, "Modern Age Aqueducts in Portugal," in Aqueducts, ed. Vittorio Gregotti (Bologna: CIPIA, 1994).

Stinger, Charles L., "Roman Humanist Images of Rome," in Roma capitale, 1447-1527, ed. Sergio Gensini (Pisa: Pacini, 1994). 